\title{
Three New Species of Saccocirrus (Polychaeta: Saccocirridae) from Hawai ${ }^{1}{ }^{1}$
}

\author{
7. H. Bailey-Brock, ${ }^{2,3}$ F. Dreyer, ${ }^{2}$ and R. E. Brock
}

\begin{abstract}
Three new species of saccocirrids from interstitial sand habitats off O'ahu, Hawai'i, are described. Two are from subtidal depths, $9-33 \mathrm{~m}$, and the third is from the intertidal to $3.5 \mathrm{~m}$ deep on a fringing reef and at Hanauma Bay, the Marine Life Conservation District and public park. The two deeper-water species, Saccocirrus oabuensis, n. sp. and S. waianaensis, n. sp., have 76-119 and 157-210 segments, respectively; they also have bilateral gonads but lack a pharyngeal pad. The third, S. alanbongi, n. sp., has 35-47 segments, unilateral gonads, and a muscular pharyngeal pad. These species are distinguished from 18 known Saccocirrus spp. by their unique chactation, number of segments, presence or absence of ventral cilia, and pygidial adhesive structures. Saccocirrus oabuensis consumes foraminiferans, and $S$. alanhongi contained diatoms, unicellular algae, and ostracods. These species add to the interstitial fauna of $O^{\prime}$ ahu and cooccur with polychaetes Nerilla antennata (Nerillidae) and protodrilids (Protodrilidae), and Kinorhyncha. Saccocirrus alanbongi withstands almost daily disturbance by $600-1200$ bathers per day entering the sandy swimming holes in the reef at Hanauma Bay.
\end{abstract}

SACCOCIRRIDS WERE FIRST recorded from Hawai'i in 1979, when they were found in sand on a shallow fringing reef near Pearl Harbor on the south shore of $\mathrm{O}^{6}$ ahu, Hawai' $\mathrm{i}$ (Bailey-Brock 1979). This unnamed species from Fort Kamehameha reef was added to the polychaete fauna as Saccocirrus sp. in a revision of C. H. Edmondson's Reef and Sbore

1 This study was funded by the Department of Environmental Services, City and County of Honolulu, $\mathrm{Ha}$ wai' $i$, under contract no. 54997 to the Water Resources Research Center, and the Hanauma Bay Carrying Capacity study to R. E. Brock. This is contributed paper CP-2003-02 of the Water Resources Research Center, University of Hawai'i at Mānoa, Honolulu. Manuscript accepted 18 December 2002.

${ }^{2}$ Water Resources Research Center, University of Hawaíi at Mānoa, 2540 Dole Street, Holmes Hall 283, Honolulu, Hawai'i 96822.

${ }^{3}$ Department of Zoology, University of Hawaici at Mānoa, 2538 McCarthy Mall, Honolulu, Hawai'i 96822.

4 University of Hawai'i Sea Grant Extension Program, 2525 Correa, Honolulu, Hawai'i 96822.

Pacific Science (2003), vol. 57, no. 4:463-478 (C) 2003 by University of Hawai'i Press

All rights reserved
Fauna of Hawai i (Bailey-Brock 1987). Saccocirridae were classified as "Archiannelida," which included Protodrilidae, Nerillidae, Dinophilidae, and Polygordiidae (Jouin 1971, Westheide 1985). This old grouping of five families has since been discarded (Westheide 1985, 1990) and all are families of Polychaeta. Westheide's papers emphasized the interstitial habitat as a unifying characteristic of eight families, including the five just listed and Protodriloidae, Diurodrilidae, and Parergodrilidae. Representatives of two families, Mesonerilla fagei and Nerilla antennata (Nerillidae) and Protodrilus sp. (Protodrilidae), are known from Hawai'i (Bailey-Brock 1987, 1999). Recently another protodrilid species, Parenterodrilus sp., was collected off Ni'ihau, Hawai'i, and awaits further study. In this paper we add three species of Saccocirrus collected from sand habitats in a shallow bay and on fringing reefs to depths of $35 \mathrm{~m}$ off O'ahu, Hawai'i.

\section{MATERIALS AND METHODS}

Collections were made by hand with a corer $7.6 \mathrm{~cm}$ in diameter by $5 \mathrm{~cm}$ deep from 0.5 - to $3.5-\mathrm{m}$ depths in Hanauma Bay and from the seaward side of the intertidal reef flat at Fort 
Kamehameha, bordering the entrance to Pearl Harbor. Scuba divers collected sediment cores of medium-grain calcareous sand off Wai'anae, and at Māmala Bay stations off the south shore of $\mathrm{O}^{\prime} \mathrm{ahu}$. Those from greater depths ( $50 \mathrm{~m}$ or more) were taken with a van Veen grab deployed from a research vessel. All were preserved in $10 \%$ buffered formalin and Rose Bengal for $24 \mathrm{hr}$ or more, elutriated over 0.50 - and $0.25-\mathrm{mm}$ mesh sieves, and stored in $70 \%$ ethanol. Preserved specimens were mounted in glycerol on slides and examined with phase contrast and dark and bright field microscopy. Magnifications for line drawings made with a compound microscope with $10 \times$ eyepieces are from 40 to $1000 \times$ with oil. Specimens of the three species were examined with scanning electron microscopy (SEM) using a field emission microscope (Hitachi S-800) operating at $15 \mathrm{KV}$ after ethanol dehydration and coating with gold-palladium. Specimens of $S$. alanbongi were dried with a critical point drier (Autosamdri-810). Specimens of the other species were air dried on parafilm in a desiccator because the drier required extensive repair or replacement. Micrographs were saved as TIFF images and prepared as plates with Adobe Photoshop.

\section{RESULTS}

Three new species of Saccocirridae Czerniavsky, 1881, found in sand collected from the south, east, and west shores of $O^{\prime}$ ahu are described here. Numerous specimens of Saccocirrus alanhongi were collected in sand from Hanauma Bay (southeastern $\mathrm{O}^{6} \mathrm{ahu}$ ) on 27 July 1999, and they were abundant (483 specimens) in coarse sands at Fort Kamehameha reef flat (southern O'ahu) collected in 1977 (Bailey-Brock 1979). Specimens of Saccocirrus oabuensis were collected in sediments adjacent to four O'ahu sewage outfalls: Wai'anae on the west, Sand Island and Barbers Point on the south, and Mōkapu on the east. Four specimens of Saccocirrus waianaensis were found off the Wai'anae sewage outfall, three off the sandy beach fronting Waimannalo on the east coast of $\mathrm{O}^{\prime} \mathrm{ahu}$, and one off Hilo Bay, Hawai'i.
Saccocirrus alanbongi Bailey-Brock, Dreyer \& Brock, n. sp.

Figures 1-4

TYPE MATERIAL: Holotype: USNM 1012494 , Hanauma Bay, O'ahu, Hawai' $i$, at depths of 0.5-3.5 m, 27 July 1999. Paratypes: UsNM 1012495-1012497, same data as holotype.

DESCRIPTION: Specimens measure 2.7$3.4 \mathrm{~mm}$ in length and $0.25-0.30 \mathrm{~mm}$ in width. Number of segments ranges between 35 and 47 (Figure 1 $A$ ). One pair of long, wrinkled cephalic tentacles measuring $0.40-0.72 \mathrm{~mm}$ extends about one-third of the body length (Figure $1 B-D$ ). The first 1 or 2 segments and posterior segments $3-11$ are achaetous. One pair of red eyes is present on the rounded prostomium (Figure $1 B$ ). Eyes present as ciliary patches (Figure $3 A, B$ ). Nuchal organs are a dorsal groove between prostomium and peristomium (Figures $1 B, C ; 2 A ; 3 A, B$ ). A muscular pharyngeal pad (Figure $1 B$ ) and ventral mouth (Figures $1 D, 2 A-C$ ) are present. Cilia are on the ventral surface of the prostomium (Figure 2A,B), around the mouth (Figure $2 A-D$ ), and in the midline to the third chaetiger (Figure 2A,B). Paddlelike cilia around the mouth may be actual features or artifacts of specimen preservation (Figure 2D). Parapodia are uniramous with 3 types of chaetae per fascicle (Figures $1 G, 3 C, 4 A$ ). The first type is longest, having a terminal fork with unequal branches and a short, serrated median projection that gives a tridentate appearance at $100 \times$ oil, 1 or 2 per fascicle (Figures $1 G, H ; 3 C, D$ ). The median region is composed of 6 short, digitiform projections (Figure $3 D$ ); one in the middle is longer and broader than the others. The secand type is a medium-length forked chaeta with equal-length prongs; margins in the fork appear smooth at $100 \times$ oil (Figure $1 G$ ), but 4-6 serrations along the distal part of the inner margins are visible with SEM (Figure $4 A), 3$ per fascicle. The third type is a short, simple chaeta with a terminal notch, $2-3$ per fascicle (Figures $1 G ; 4 A, C$ ). Clusters of 3 peglike structures and a few single apertures (Figure $4 B$ ) were evident across the ventrum of anterior segments. Pegs are possibly solidified adhesive material and the holes remain 


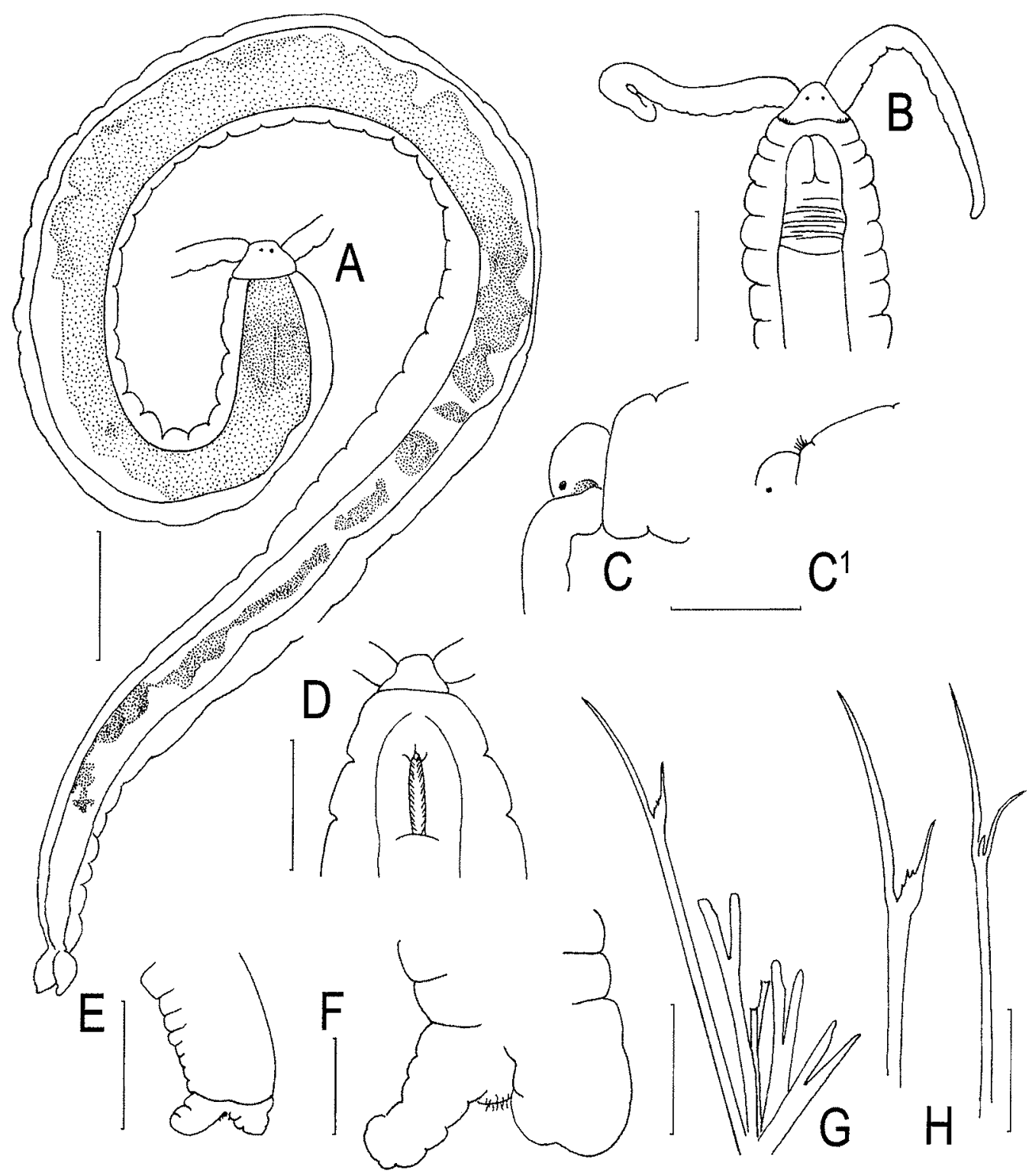

Figure 1. Saccocimus alanhongi. $A$, Entire worm, dorsal to lateral view; $B$, anterior, dorsal view, prostomium, peristomium, cephalic tentacles, apertures of nuchal organs, pharyngeal pad; $C$, anterior, lateral view, groove defining nuchal organs; $C^{1}$, nuchal organ cilia; $D$, anterior, ventral view; $E, F$, papillate pygidium; $G$, three types of chaetae; $H$, long chaetae $\left(G, H 100 \times\right.$ oil). Scales: $A, 0.2 \mathrm{~mm} ; B, C, C^{1}, D, 0.1 \mathrm{~mm}, E, 0.2 \mathrm{~mm} F, 0.05 \mathrm{~mm} ; G, 0.01 \mathrm{~mm}, H, 0.02 \mathrm{~mm}$.

when the material is extruded. Gonads are assumed to be unilateral due to the presence of the pharyngeal pad, and one specimen was collected with eggs on one side of the gut. Pygidium bifurcated (trifurcated in 1 speci- men), lobes $0.06-0.15 \mathrm{~mm}$ in length, each lobe with 4-6 ridges with adhesive papillae on the inner surface, without anal cirri (Figures $1 E, F ; 4 D$ ).

REMARKS: Long chaetae resemble those 

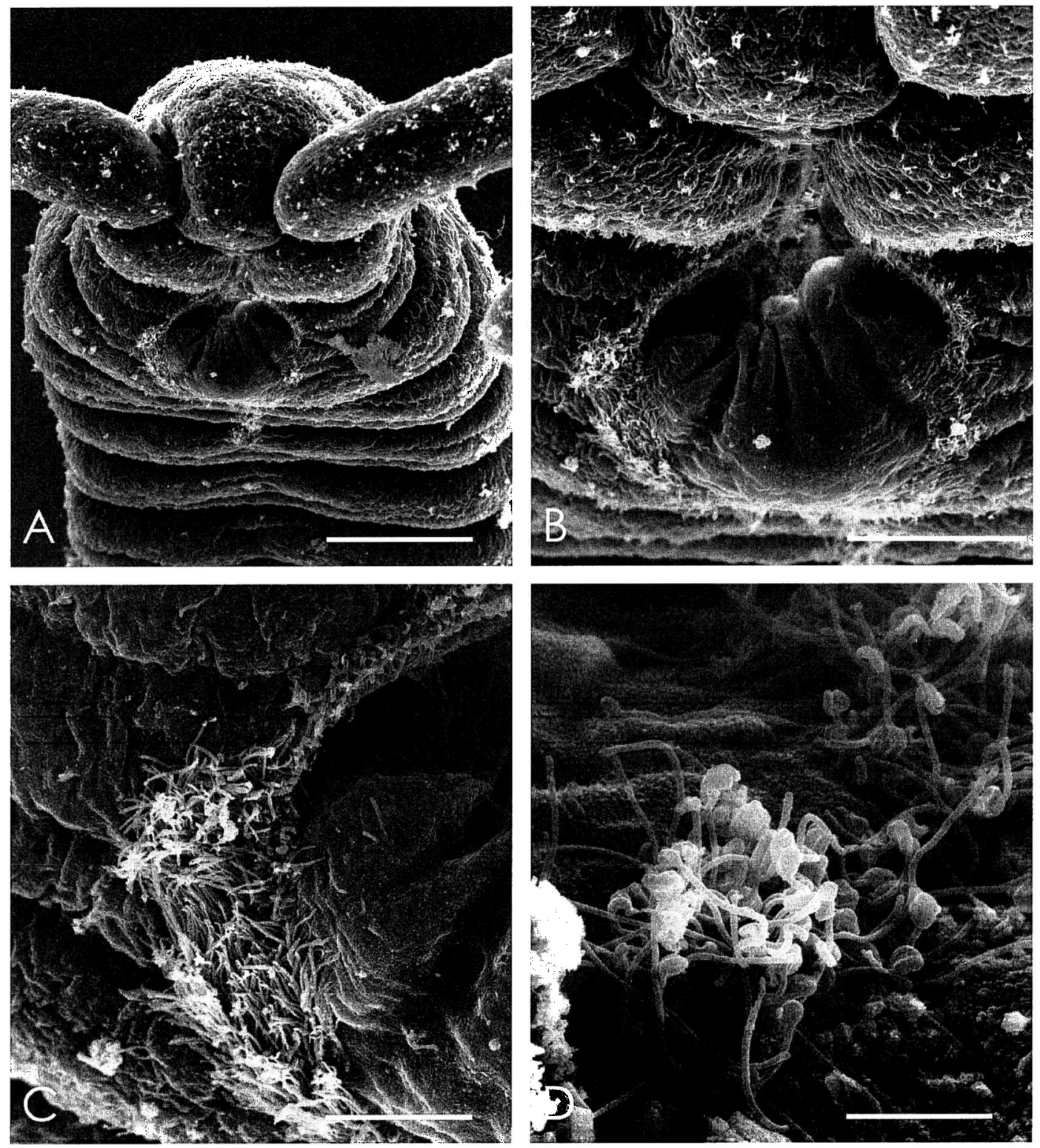

FIGURE 2. Scanning electron micrographs of Saccocimris alanbongi. $A$, Anterior region, view of cephalic tentacles, nuchal organs, and mouth; $B$, mouth surrounded by cilia, ventral groove cilia, and folded oral membrane; $C$, peristomial cilia and oral membrane; $D$, paddlelike peristomial cilia (see text for discussion). Scales: $A, 60 \mu \mathrm{m} ; B, 30 \mu \mathrm{m} ; C, 10.0 \mu \mathrm{m} ; D$, $3.8 \mu \mathrm{m}$.

of Saccocirrus tridentiger Brown, 1981, but the Australian species has a curved short branch and three chaetae per fascicle whereas $S$. alanbongi has only one long chaeta (in one rare occurrence observed only in SEM, two were present). Medium chaetae number two to four in $S$. tridentiger and two to three in $S$. alanhongi. Pygidial adhesive papillae differ: $S$. tridentiger has 6-14 papillar ridges, and the Hawaiian species has four, rarely six. Saccocir- 

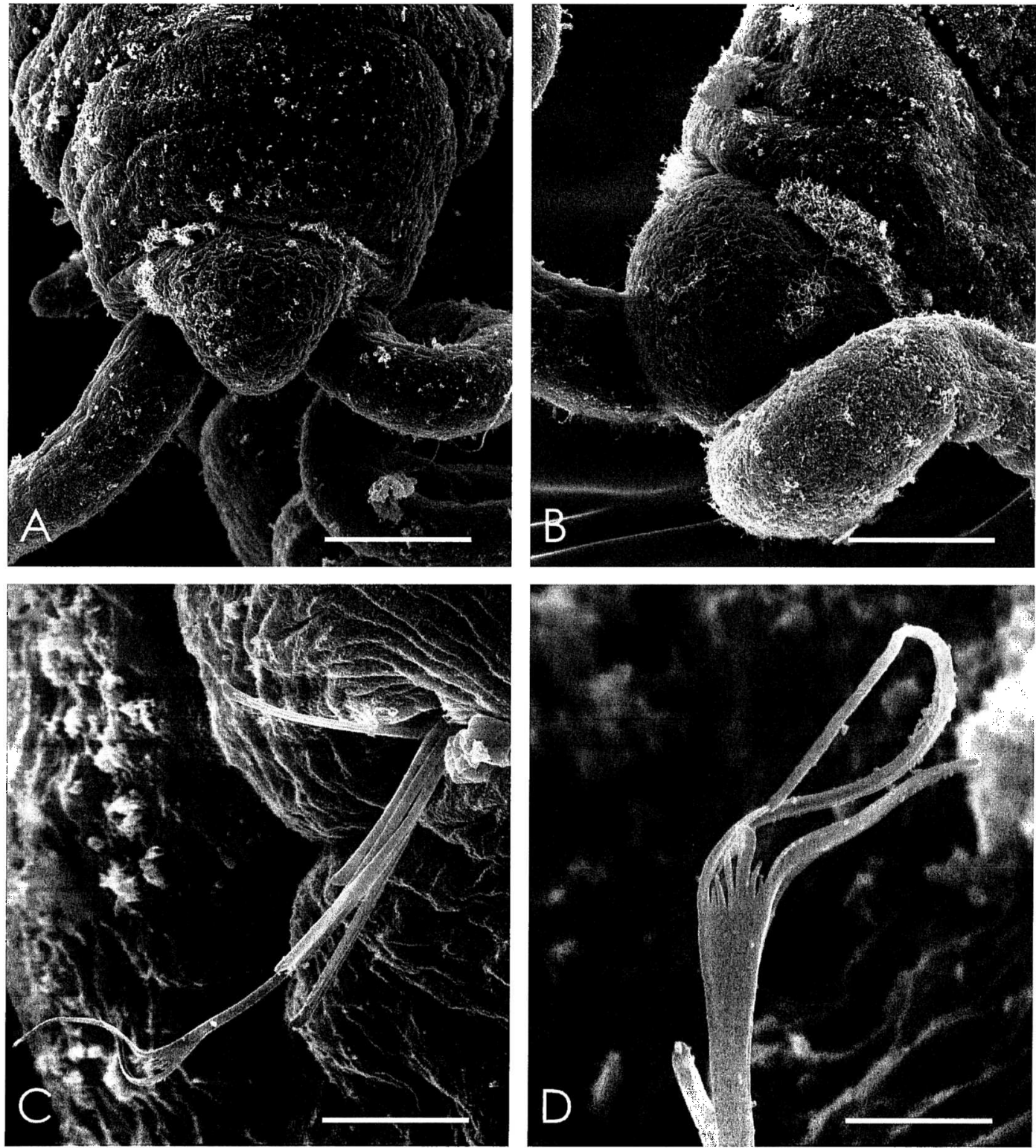

FiguRE 3. Scanning electron micrographs of Saccocimrus alanbongi. $A$, Anterior region, dorsal view; $B$, anterior region, lateral view showing nuchal organs and left eye; $C$, fascicle with three kinds of chaetae; $D$, long chaeta. Scales: $A, 60 \mu \mathrm{m}$; $B, 43 \mu \mathrm{m} ; C, 8.6 \mu \mathrm{m} ; D, 3.0 \mu \mathrm{m}$.

mus alanbongi is substantially smaller (up to 3.4 $\mathrm{mm}$ ) with fewer segments (up to 47) than the Australian species, which has 62-98 segments measuring up to $20 \mathrm{~mm}$. Ciliation of the midventral groove to chaetiger 8 is present in
S. tridentiger; $S$. alanbongi has ventral ciliation below the mouth to the third chaetiger and cilia on the prostomium and peristomium near the mouth. It differs from Saccocirrus krusadensis Alikunhi, 1948, from India, which 

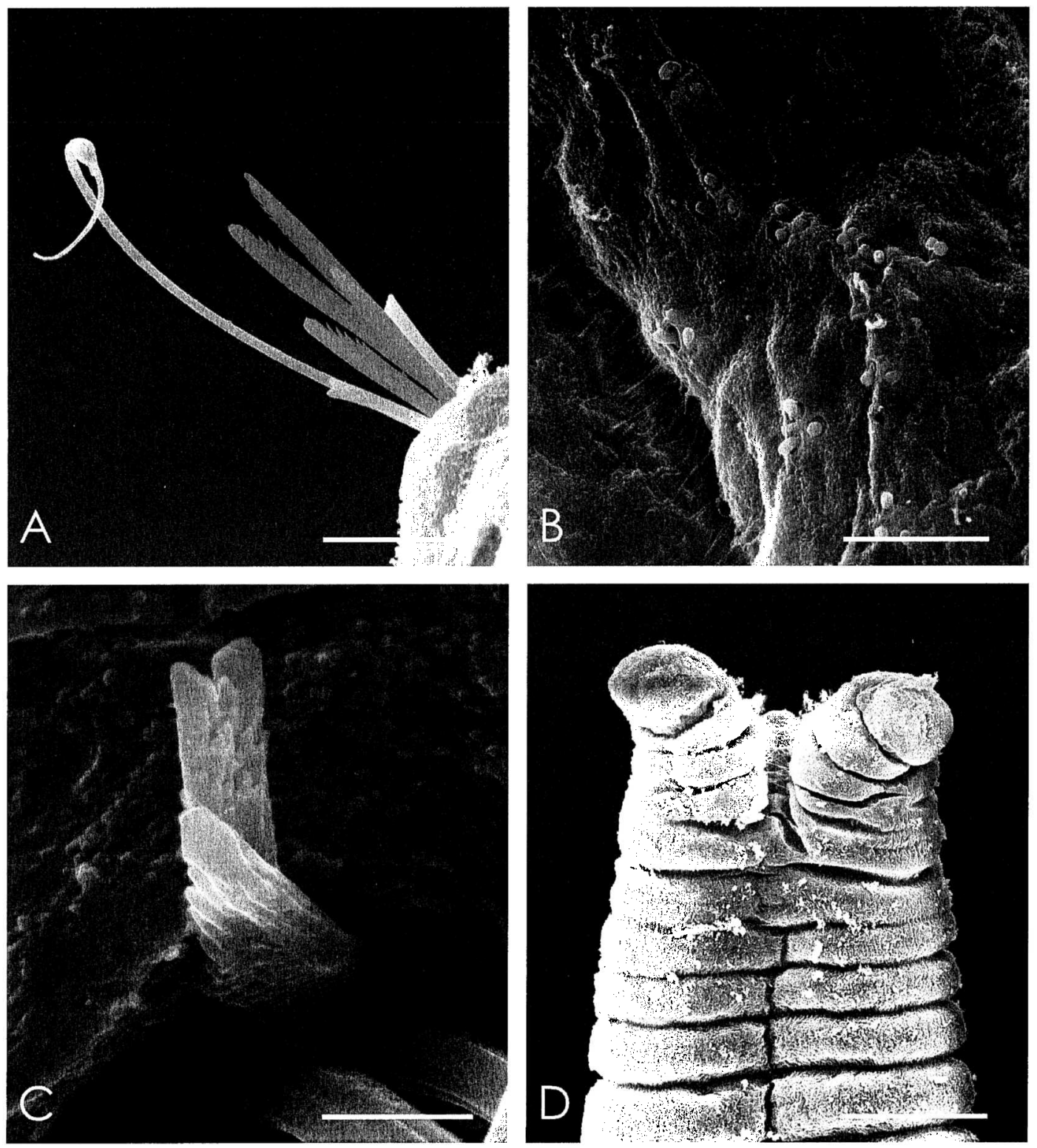

FigURE 4. Scanning electron micrographs of Saccocimus alanbongi. $A$, Serrate inner margins of forked chaetae; $B$, peg structures and apertures across ventrum; $C$, short chaetae; $D$, pygidium and adhesive papillae. Scales: $A, 10.0 \mu \mathrm{m} ; B$, $7.5 \mu \mathrm{m} ; C, 1.5 \mu \mathrm{m}, D, 50 \mu \mathrm{m}$.

lacks the middle prong in the long chaetae (also not present in S. krusadensis from Australia). The long chaetae of S. alanbongi are very similar to those of $S$. krusadensis from Laccadive and Moorea (Jouin and Rao 1987).
The forked chaetae of S. krusadensis from India have obvious serrations on the inner margin (at $1750 \times$ in Alikunhi 1948, fig. 2b), like those shown with SEM from Laccadive, Moorea, and Durban (Jouin and Rao 1987). 
The serrations in $S$. alanbongi chaetae are confirmed only with SEM. Curvature and flat plane of chaetae are often distorted in SEM preparation. Tips of long bifurcate chaetae twist; fork branches of forked chaetae may fold against each other or each branch twist into a spiral; and the serrate margin rolls into the fold to appear asymmetrically serrated compared with the other fork. Saccocirrus krusadensis has 100-150 segments and measures $20-25 \mathrm{~mm} ; S$. alanbong $i$ has only up to 47 segments and measures $2.7-3.4 \mathrm{~mm}$. The Moorea $S$. krusadensis has more papillar ridges and longer pygidial lobes than $S$. alanbongi. Saccocirrus alanbongi is distinguished from these other two species based on (1) body size, (2) number of segments, (3) extent of the midventral groove ciliation, (4) pygidial lobe length, and (5) number of papillar ridges.

MATERIAL EXAMINED: Thirty or more specimens from Hanauma Bay and four specimens from Fort Kamehameha intertidal reef flat (Bailey-Brock 1987). Five specimens from Hanauma Bay were measured and segments counted, and five were examined with SEM.

ETYMology: Saccocirrus alanhongi is named for Alan Hong, Department of Parks and Recreation, City and County of Honolulu, lifelong caretaker of Hanauma Bay.

\section{Saccocirrus oabuensis Bailey-Brock, Dreyer \& Brock, n. sp. \\ Figures 5, 6}

TYPE MATERIAL: Holotype: USNM 1012490 , Māmala Bay station 4 (station designations are given in Swartz et al. 2002), $21^{\circ} 17^{\prime} 07^{\prime \prime} \mathrm{N}$, $158^{\circ} 05^{\prime} 28^{\prime \prime} \mathrm{W}$ at 9.4-m depth near Barbers Point, O'ahu, Hawai'i, 11 August 2001. Paratypes: USNM 1012491, same data as holotype.

DESCRIPTION: Specimens measure $8.40-$ $10.45 \mathrm{~mm}$ in length and $0.3-0.4 \mathrm{~mm}$ in width. One pair of lightly articulated cephalic tentacles measuring $1.25-1.4 \mathrm{~mm}$ in length (Figure $5 A-C$ ) is present. Number of body segments ranges between 76 and 119 . The first segment is achaetous (except in one specimen where the first 3 segments were achaetous), and 5-8 posterior segments are achaetous. One pair of red eyes is present on the bluntly rounded prostomium (Figure $5 A$ ). Nuchal organs are present in some specimens (Figure $5 B$ ) but are not easily observed with light or scanning microscopy. Cilia were not visible on the head or anterior segments (Figure 6A). Without a muscular pharyngeal pad. Parapodia are uniramous with 3 types of chaetae in each fascicle (Figures $5 I ; 6 B-D$ ). The first type is the longest, having an asymmetrical bifid tip, 1 per fascicle (Figure $6 B$ ). The second type is a medium-length forked chaeta (Figure $6 C, D$ ) with 2 inner points, 3--4 per fascicle (Figure $5 I$ ). The third type is a short, blunt-tipped simple chaeta with small apical teeth, 3 per fascicle. Gonads are bilateral, and eggs are present in all type specimens. Two developmental stages, based on egg size, were seen. Pygidium bifurcated (Figures 5D-H; 6C,D), lobes $0.14-0.20 \mathrm{~mm}$ in length, each lobe with 5-6 ridges with adhesive papillae on the inner surface (Figure $5 D-H)$. Pygidium with anal cirri (Figure $5 E, F)$ in some specimens examined (1 specimen illustrated without anal cirri [Figure $5 \mathrm{H}]$ ). The anal cirri detached from the dried specimens during mounting for SEM (Figure $6 E)$. Pygidial palpocils are visible in others (Figure $\left.5 G, G^{1}\right)$. Tufts of cilia were seen on the pygidium and posterior achaetous segments and on the palpocils (Figure $5 G^{1}$ ).

REMARKs: Saccocirrus oabuensis resembles Saccocirrus cirratus Aiyar \& Alikunhi, 1944, S. parvus Gerlach, 1953, and Saccocirrus minor Aiyar \& Alikunhi, 1944: all three have bilateral gonads and somewhat similar chaetae. It differs from them in the structure of long chaetae, which terminate as broad, blunt chisels in $S$. minor and bifid chaetae with unequal blunt tips in $S$. cirratus and $S$. parvus. In $S$. oabuensis one arm of the bifid tip is longer and the width of each arm is less than in the other species. Medium chaetae of S. oabuensis are forked, with a pair of needlelike points in the crotch of the fork and an incision (Figure $6 D$ ). Medium chaetae of the other species have blunt tips without a fork or incision. Size and number of segments vary in all four species, with $S$. oabuensis being intermediate, measuring up to $10.45 \mathrm{~mm}$ long with 119 segments. In contrast, $S$. cirratus measures $40-45 \mathrm{~mm}$ long with up to 200 segments, $S$. 


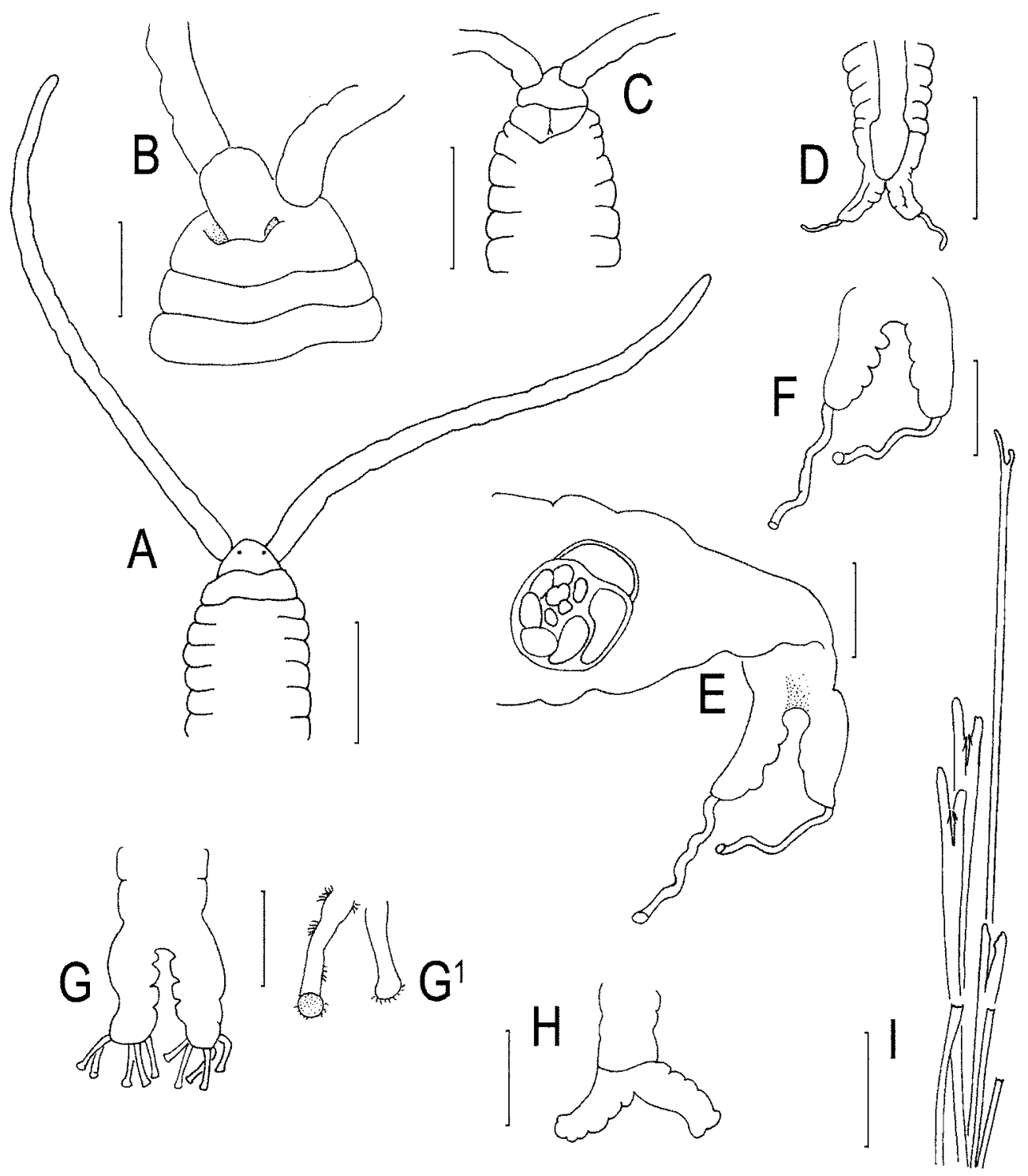

Figure 5. Saccocimus oabuensis. $A$, Anterior region, dorsal view; $B$, anterior, lateral view, cephalic tentacles and nuchal organs; $C$, ventral view, position of the mouth; $D$, bifurcate pygidium with anal cirri; $E$, posterior region with a foraminiferan in the gut; $F$, pygidium with papillae and anal cirri; $G$, pygidium with extruded palpocils; $G^{1}$, palpocils with swollen tips and tufts of cilia; $H$, pygidium of specimen missing anal cirri; $I$, three types of chaetae. Scales: $A-D$, $0.02 \mathrm{~mm} ; E, 0.075 \mathrm{~mm} ; F, 0.02 \mathrm{~mm} ; G, 0.02 \mathrm{~mm} ; G^{1}$, enlargement of $G ; H, 0.02 \mathrm{~mm} ; I, 0.05 \mathrm{~mm}$.

minor measures $10-15 \mathrm{~mm}$ long with $70-100$ segments, and $S$. parvus measures $2.5-3.0 \mathrm{~mm}$ long with up to 48 segments. Saccocimus cirratus has a muscular pharyngeal pad, but $S$. oabuensis does not. Saccocirrus cirratus has ex- panded pygidial lobes with adhesive margins without papillae but possesses long, slender anal cirri; $S$. parvus has broad pygidial lobes without papillae; and S. minor lacks or has very reduced pygidial lobes and no papillae (Aiyar 

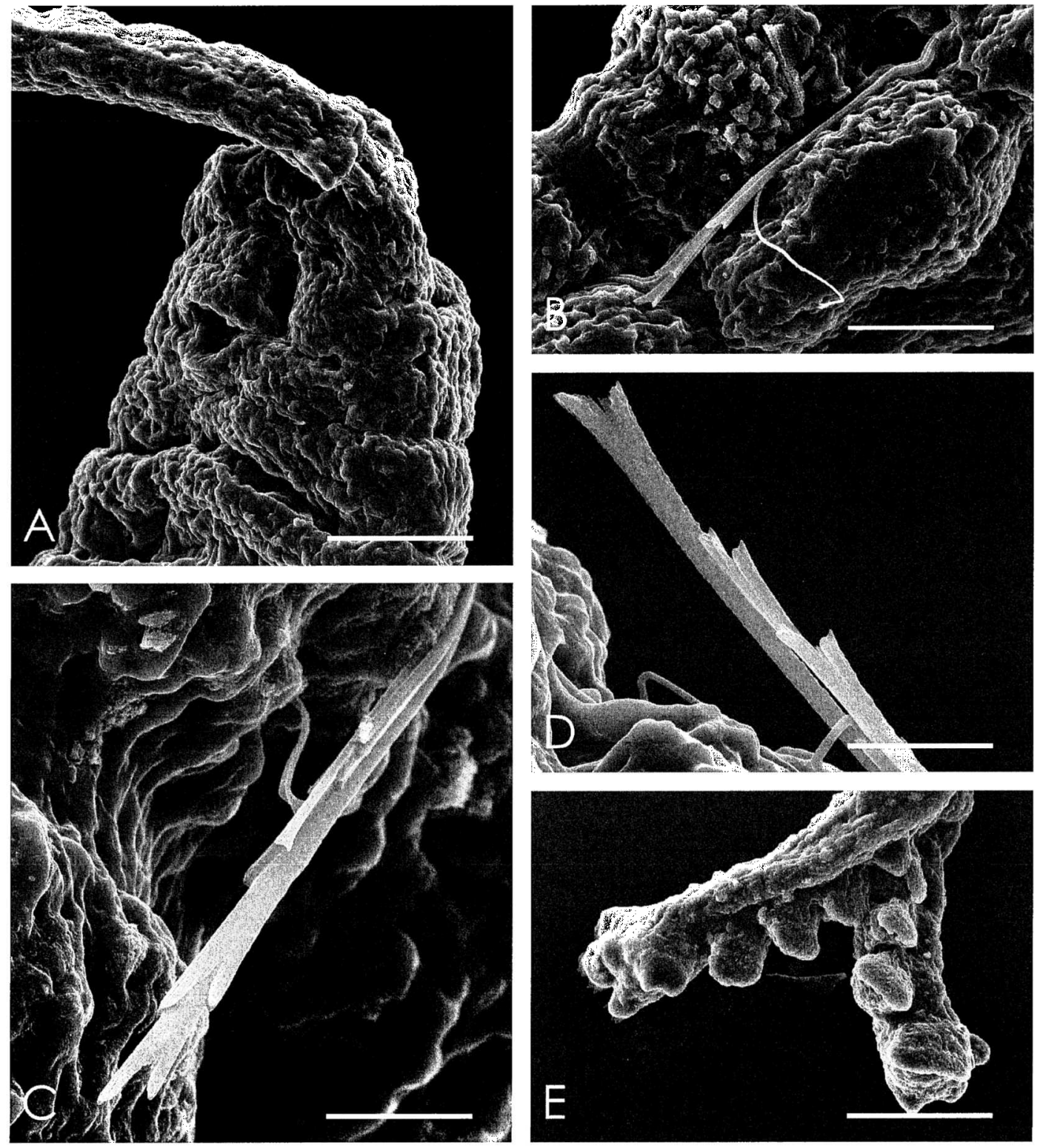

Figure 6. Scanning electron micrographs of Saccocirrus oabuensis. $A$, Anterior region, ventrolateral view showing mouth and absence of cilia; $B$, fascicle showing a slender long chaeta (bent) and stout forked chaetae; $C$ and $D$, short and forked chaetae; $E$, pygidial lobes with adhesive papillae (cirri lost in preparation). Scales: $A, 50 \mu \mathrm{m} ; B, 38 \mu \mathrm{m}$; $C, 12.0 \mu \mathrm{m} ; D, 12.6 \mu \mathrm{m} ; E, 43 \mu \mathrm{m}$.

and Alikunhi 1944, Jouin and Rao 1987). In contrast, $S$. oabuensis has five to six pygidial papillae and short anal cirri or palpocils.

MATERIAL EXAMINed: More than 35 specimens from Māmala Bay and Mōkapu.
Five specimens were measured and segments counted, and five were examined with SEM.

ETYMOLOGY: Saccocirrus oabuensis is named for $\mathrm{O}^{6} \mathrm{ahu}$, the island where the city of Honolulu and Waikīkī Beach are located. 
Saccocirrus waianaensis Bailey-Brock, Dreyer \& Brock, n. sp.

Figures $7-10$

TYPE MATERIAL: Holotype: USNM 1012492 , sand sediments adjacent to Wai'anae ocean outfall station W1R2 (station designations are given in Russo et al. 1997), O'ahu, Hawai'i, at 31.4-m depth, 13 May 2001. Paratypes: UsNM 1012493, same locality as holotype but from station W9R4 at 32.9-m depth, 20 July 1997.

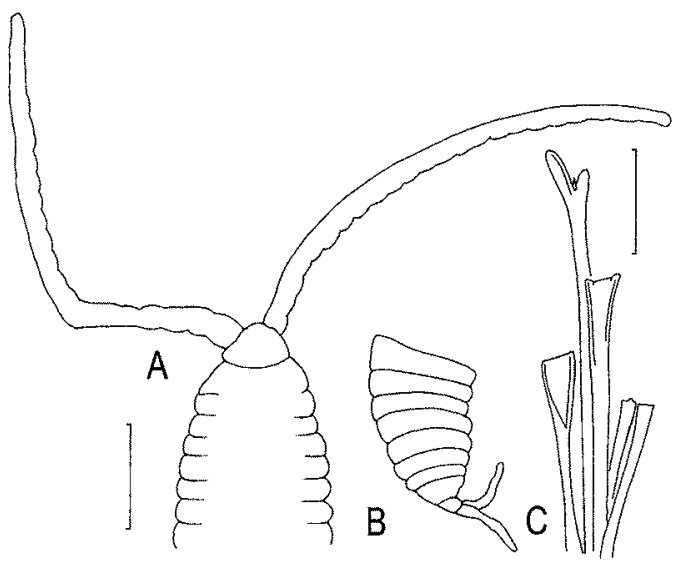

Figure 7. Saccocirrus waianaensis. A, Anterior region, dorsal view; $B$, posterior with bifurcate pygidium; $C$, three types of chaetae. Scales: $A, B, 0.01 \mathrm{~mm} ; C, 0.02 \mathrm{~mm}$.
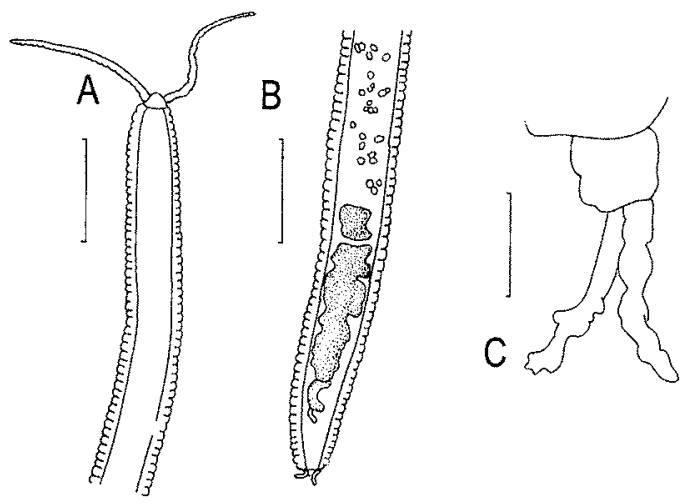

Frgure 8. Saccocirrus waianaensis. A, Anterior region, dorsal view; $B$, middle and posterior regions with eggs and gut contents indicated (shaded); $C$, pygidium with anal cirri. $A$ and $B$ are of the same specimen. Scales: $A, B$, $0.2 \mathrm{~mm} ; C, 0.1 \mathrm{~mm}$.
DESCRIPTION: Specimens measure 8.4$10.0 \mathrm{~mm}$ in length and $0.33-0.45 \mathrm{~mm}$ in width (Figures $7 A ; 8 A, B$ ). Number of body segments ranges from 157 to 210 . There is 1 pair of lightly articulated cephalic tentacles measuring $0.90-1.31 \mathrm{~mm}$ in length (Figures $7 A, 8 A)$. There are no anterior achaetous segments, but 5-9 posterior achaetous segments are present. Prostomium is rounded. Eyes were not observed in these specimens (Figures $7 A, 8 A$ ). Nuchal organs, a muscular pharyngeal pad, and ventral cilia patches were not observed with light microscopy or SEM (Figure $9 A, B)$. Lower lip of mouth on the ventral surface is crenulated (Figure $9 B$ ). Parapodia uniramous with 3 types of chaetae (Figures $7 C ; 9 C ; 10 A, B, D)$. The first type is the longest (but its length is intermediate in comparison with long chaetae of S. oabuensis and $S$. alanbongi) with an unequal trifid tip (Figure 9C), with the median arm being the shortest, 1 chaeta per bundle. These trifid chaetae are longest in posterior segments (88-96). The second type is a sturdy symmetrical forked chaeta, intermediate in length, deeply incised, with distal margins of the fork appearing smooth, and a hood reaching across both arms of the fork (Figures $7 C ; 10 C$ ). There are 1 or 2 forked chaetae per fascicle. The third type is the shortest, with 2 small apical teeth, with $2-3$ per fascicle (Figures $7 C ; 9 D$ ). The pygidium is bifurcate and bears 2 anal cirri from 0.08 to $0.25 \mathrm{~mm}$ in length (Figures $7 B ; 8 C$ ). No distinct adhesive papillate ridges are obvious, but anal cirri are slightly articulated (Figure $8 C$ ). Reproductive characters were observed in the paratype only. Gonads are bilateral. The number of eggs in each reproductive segment varied (Figure $8 B$ ).

REMARKS: Chaetae resemble those of $S$. parvus from the Gulf of Naples (Gerlach 1953). In $S$. parvus the longest is bifurcate with branches of unequal length but lacks the median spine seen in $S$. waianaensis. There are similarities to the shape of the mediumlength chaetae of $S$. minor from India (Aiyar and Alikunhi 1944) and $S$. parvus, but these two species lack the fork or incision that is clearly present in $S$. waianaensis. 

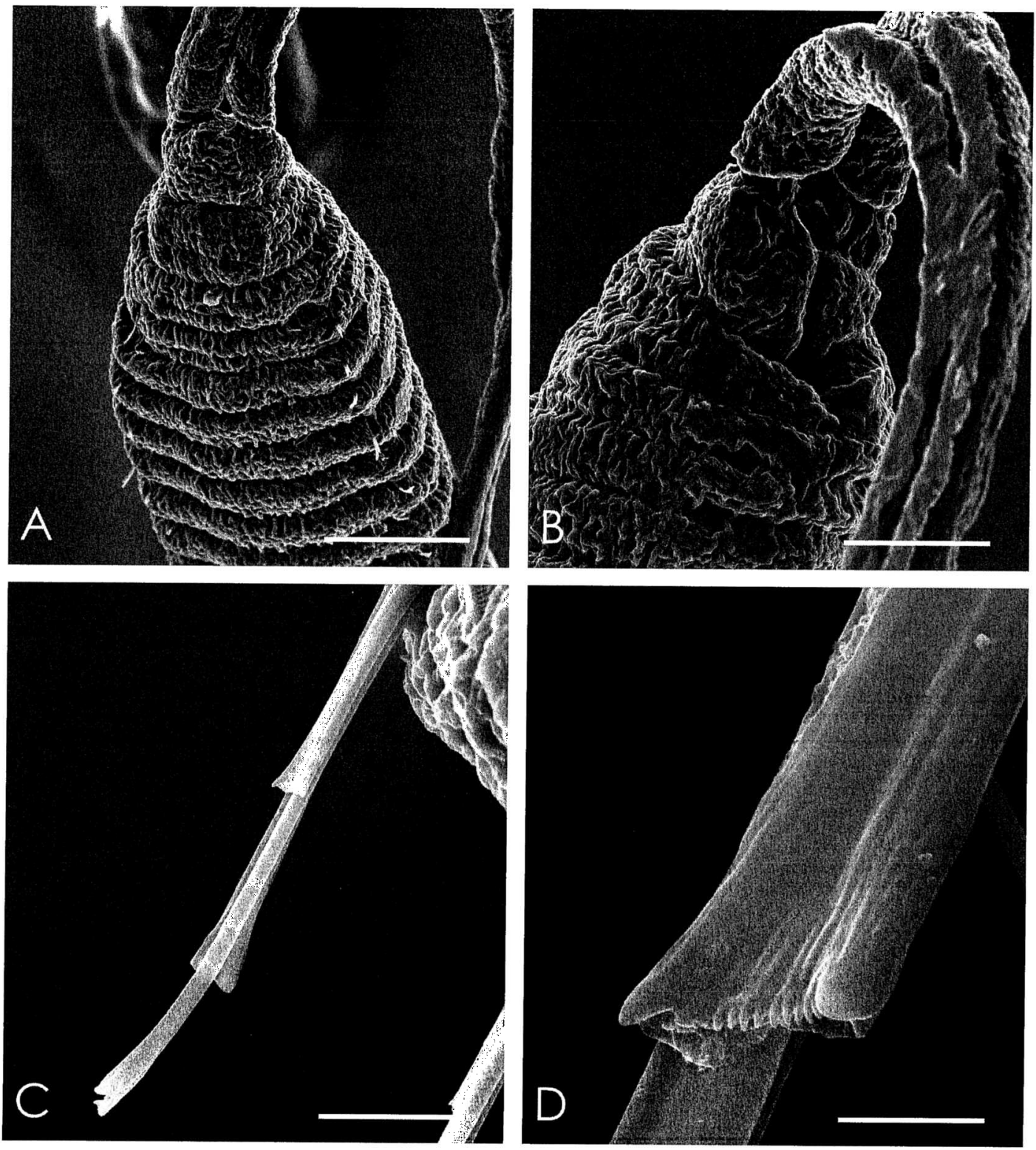

FIGURE 9. Scanning electron micrographs of Saccocimus waianaensis. $A$, Anterior region, dorsal view, showing segments and chaetae; $B$, anterior region, lateral view, with mouth and absence of cilia; $C$, fascicle with three chaetae; $D$, finely toothed terminal margin of chaeta. Scales: $A, 100 \mu \mathrm{m} ; B, 60 \mu \mathrm{m} ; C, 13.6 \mu \mathrm{m} ; D, 2.5 \mu \mathrm{m}$.

MATERIAL EXAMINED: Four specimens from Wai'anae were measured and segments counted, and two specimens were examined with SEM. Eyes were not seen; they may be minute and inconspicuous, as described for $S$. cirratus, or hard to distinguish due to lengthy storage in ethanol. Three specimens collected more recently from Waimānalo in eastern 

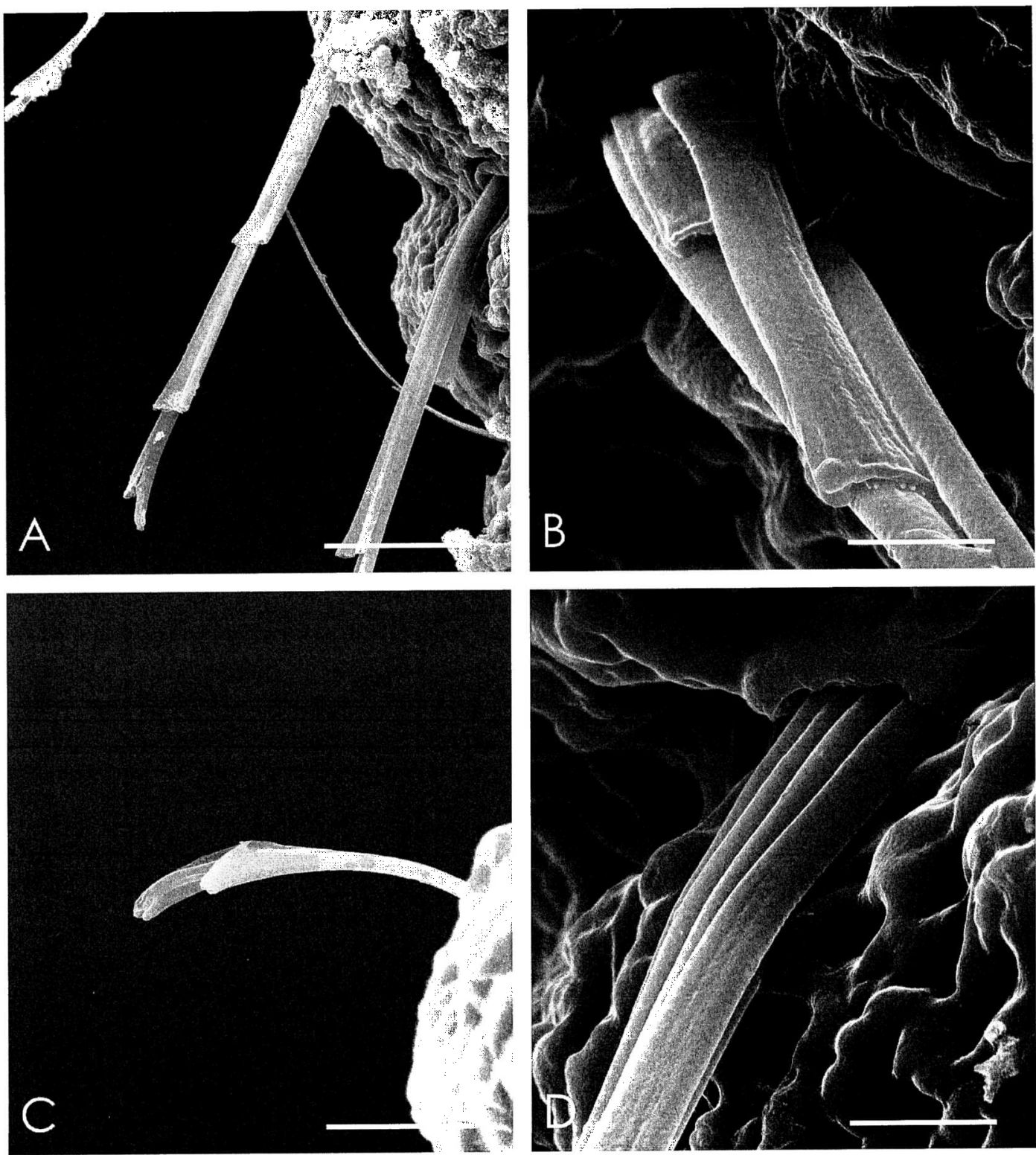

FIgURE 10. Scanning electron micrographs of Saccocimrzs waianaensis. $A$, Chaetae; $B$, fascicle with four apparent chaetae; $C$, forked and longest chaetae; $D$, four chaetae emerging at the base of a fascicle. Scales: $A, 17.6 \mu \mathrm{m} ; B, 4.3 \mu \mathrm{m}$; $C, 8.6 \mu \mathrm{m} ; D, 5.0 \mu \mathrm{m}$.

O'ahu also lacked eyes, so it is probable that S. waianaensis lacks eyes. These recently found specimens were in a sand pocket among coral rubble and live coral colonies
(Porites lobata Dana) at a depth of $2.58 \mathrm{~m}$ near the end of Makai pier. One specimen was collected off Hilo Bay, Hawai' $i$, in coarse sand at a depth of $5.6 \mathrm{~m}$. 
ETymology: Saccocirrus waianaensis is named for the type locality, Wai'anae, a coastal town in leeward O'ahu.

\section{DISCUSSION}

Saccocirrids are interstitial polychaetes, formerly considered primitive "Archiannelida" due to their small size and simple body plan. They are highly modified from the typical biramous parapodium-bearing polychaete, having cylindrical uniramous parapodia without acicula, three or four kinds of chaetae that are often forked, fluid-filled palps with ampullae, and reproductive segments with ova and sperm-filled spermathecae. Viviparity has been described in some saccocirrids (Silberbauer 1969). These small polychaetes with adhesive glands on papillae or ventral epithelium are well adapted to interstitial and highenergy habitats (Westheide 1990). Chaetae are present in Saccocirridae, Nerillidae, and some Protodriloidae and are absent from Polygordiidae, Protodrilidae, and Dinophilidae. Chaetation of saccocirrids is very different from that of the other two families. Nerillids have many more chaetae per fascicle than saccocirrids, and Protodriloidae lack parapodia but have sigmoid chaetae or segmental adhesive glands. Saccocirrids are closest to protodrilids (lack parapodia and chaetae) and protodriloids (with chaetae).

Protodrilidae and Saccocirridae were classified in the order Protodrilida by Pettibone (1982) and in Canalipalpata (united by having hollow palps) by Rouse and Fauchald (1997). Saccocirridae contains a single genus, Saccocirrus Bobretsky, 1872, and are known from sand habitats around the world (Brown 1981).

The 18 known species are placed in two groups. One group includes those with bilaterally situated gonads; the other group has, with one exception (Saccocirrus burcbelli Silberbauer), unilateral gonads. Those with bilateral gonads are usually without a muscular pharyngeal pad (except for S. cirratus) and lack cilia in the peristomial and ventral grooves. Those with unilateral gonads usually have a muscular pharnyngeal pad; peristomial and ventral groove cilia; and long, furcate chaetae (Brown 1981, Sasaki 1981). Pygidial palpocils were seen in specimens of $S$. oabuensis (Figure 5G, $G^{1}$ ).

The three species of saccocirrids are from very different habitats. Saccocirrus alanbongi specimens are found in sand of shallow, highenergy, and frequently trampled or disturbed habitats. Saccocirrus oabuensis is found in coarse-grain sands from subtidal depths in Māmala Bay, Mōkapu, and Honolulu Harbor, and $S$. waianaensis is found at $30-$ to $33 \mathrm{~m}$ depths off Wai'anae, $2.58 \mathrm{~m}$ off Waimānalo and $5.6 \mathrm{~m}$ off Hilo. Saccocirrids adapt to high water motion conditions from surf and tidal change. Their adhesive glands attach to sand grains, which keep them on the bottom. Sand grains attached to anal papillae and adhesive glands provide a "weight belt" to reduce buoyancy and increase sinking following resuspension due to wave backwash. The Hanauma site is a public beach and Marine Life Conservation District that has 600-1200 bathers entering and leaving the water per day and trampling through the saccocirrid sand habitat. The water adjacent to the beach is an area frequented by mixed schools of adult and juvenile (less than $3 \mathrm{~cm}$ in length) Mugil cepbalus (mullet), Kublia sandvicensis (flagtails, āholehole), and Mulloidichtbys vanicolensis (goatfish). Some of these fish may pick small invertebrates from the sand and suspended in the water column. The fish avoid potential predators by patrolling the beach margin and benefit from sand disturbance by bathers. Saccocirrids may be components of their diet, but this assumption is hypothetical without gut content studies. Saccocirrids have been described as carnivorous, with fish and copepods in the gut (Jouin 1971). Similarly, $S$. alanhongi guts have been observed to contain fragmented material (most likely bacteria, algal cells, and diatoms), a copepod, and foraminiferans. The muscular pharynx may function here, and for others in this group, as a way to crush large particles. One $S$. alanbongi specimen (mounted on a glass slide with a coverslip) had everted the anterior gut contents, and shards of diatom frustules and dark green material were seen. Preserved specimens of $S$. oabuensis had guts containing 
foraminiferans that are readily seen with light microscopy (Figure 5E). The benthic invertebrates at $0.5-\mathrm{m}$ depth in the trampled zone at Hanauma retained on the $0.5-\mathrm{mm}$ sieve were saccocirrids and nematodes only. The benthos retained on the $0.25-\mathrm{mm}$ sieve included saccocirrids, harpacticoid copepods, mites, ostracods, acoels, nematodes, and $\mathrm{Ne}$ rilla antennata. Such low diversity at the $0.5-\mathrm{m}$ site suggests a highly perturbed environment close to shore. The Keyhole site at Hanauma (3.5 $\mathrm{m}$ deep) had more diverse benthic communities retained on $0.5-\mathrm{mm}$ and $0.25-\mathrm{mm}$ sieves, with gammarid amphipods and nematodes being most abundant. In the $0.25-\mathrm{mm}$ sieve fraction syllids, dorvilleids, spionids, and kinorhynchs were more abundant than saccocirrids, Protodrilus sp., Nerilla antennata, and Mesonerilla fagei. Saccocirrid densities were 12,760 individuals per square meter at $0.5-\mathrm{m}$ depth and up to 9020 individuals per square meter at 3.5-m depth.

The Fort Kamehameha reef community was much more diverse and richer in invertebrate fauna when sampled in 1977. Water motion averaged $9.8 \mathrm{~cm} / \mathrm{sec}$ at the sampling site on the seaward reef margin. Saccocirrid density was 9660 individuals per square meter, and none was found at the other reef flat sites. The greatest percentage of coarse grains were here, and saccocirrids were the most abundant polychaetes collected in sand (Bailey-Brock 1979). Despite being accessed from military bases, the reef is used by recreational fishers and commercial seaweed collectors. There is some foot traffic at low tides, but this is minimal compared with the daily activity at Hanauma Bay.

The saccocirrids known to date are as follows: species without the pharyngeal pad and with bilateral position of the gonads ( $S$. papillocerus Bobretzky, 1872; S. major Pierantoni, 1907; S. minor Aiyar \& Alikunhi, 1944; S. orientalis Alikunhi, 1946; S. pussicus Marcus, 1948; S. parous Gerlach, 1953; S. archiboldi Kirsteuer, 1967; S. beterochaetus Jouin, 1975); one with a pharyngeal pad (S. cirratus Aiyar \& Alikunhi, 1944); and those with unilateral position of the gonads and a pharyngeal pad (S. gabriellae Marcus, 1946; S. krusadensis Alikunhi, 1948; S. eroticus Gray, 1969; S. burcbelli
Silberbauer, 1969; S. labilis Yamanishi, 1973; S. sonomacus Martin, 1977; S. ucbidai Sasaki, 1981; S. jouinae Brown, 1981; S. tridentiger Brown, 1981).

\section{CONCLUSIONS}

The three new species of saccocirrids add to the interstitial fauna of Hawaiian sand habitats. Two belong to the subgroup having bilateral gonads and the third to the group with a muscular pharynx and unilateral gonads. Saccocirrus alanbongi occupies shallow subtidal and intertidal habitats with high water motion. Saccocirrus oabuensis and S. waianaensis are from deeper sand habitats below the highenergy habitats of reef flats and beaches. All three species are smaller than most other saccocirrids. Three species from Australia measure $20 \mathrm{~mm}$ long, from India $S$. minor $10-15 \mathrm{~mm}$ and $S$. cirratus $40-45 \mathrm{~mm}$, and $S$. ucbidai from Japan is $20 \mathrm{~mm}$ long (Sasaki 1981). In general, Hawaiian polychaetes are smaller than their close relatives from continental margins and cooler latitudes, but the differences here cannot be attributed to immature or subadult condition of specimens because reproductive characters were observed in all three species. The three new species are distinguished from others based on size, chaetal characters, and number of segments.

\section{ACKNOWLEDGMENTS}

We are grateful to many who assisted with different phases of this study, including A. Kam for expertise in the field and the Department of Land and Natural Resources for permission to collect in Hanauma Bay. $M$. McGurr and J. Dreyer arranged the figures, and A. Fukunaga prepared the plates with Photoshop. S. Monden, Zoology Department staff artist, made line drawings with a drawing tube from glycerol mounts of the three species. Wormlab staff sorted the sewage outfall samples and prepared some specimens of $S$. alanbongi for preliminary SEM. T. Carvalho of the Biological Electron Microscope Facility advised on specimen preparation and SEM for the plates. K. Tanoue, Water Re- 
sources Research Center, provided editorial advice. We thank the City and County of Honolulu, Department of Environmental Services Oceanographic team for collecting at the sewage outfalls.

\section{Literature Cited}

Aiyar, R. G., and K. H. Alikunhi. 1944. On some archiannelids of the Madras Coast. Proc. Natl. Inst. Sci. India 10 (1): 113-140.

Alikunhi, K. H. 1946. On a new species of Saccocirrus from the Madras Beach. Curr. Sci. (Bangalore) 15:149.

- 1948. On some archiannelids of the Krusadai Island. Proc. Natl. Inst. Sci. India 14 (8): 373-383.

Bailey-Brock, J. H. 1979. Sediment trapping by chaetopterid polychaetes on a Hawaiian fringing reef. J. Mar. Res. 37 (4): 643-656. . 1987. Phylum Annelida. Section 3, chapter 2, pages 213-454 in D. M. Devaney and L. G. Eldredge, eds. Reef and shore fauna of Hawaici. Section 2: Platyhelminthes through Phoronida and Section 3: Sipuncula through Annelida. Bernice P. Bishop Mus. Spec. Publ. 64:213-454.

- 1999. Nerillidae of Hawai' $\mathrm{i}$ : Two new records of interstitial polychaetes. Pac. Sci. 53 (3): 299-304.

Bobretzky, N. V. 1872. Saccocirrus papillocerus, n. gen., n. sp. 'Tip' novago semeistra annelid. Sravmitel'no-Anatomichskii obcherk. Mem. Kiev. Univ. Odsch. Estest. Zapisky 2:211-259.

Brown, R. 1981. Saccocirridae (Annelida: Archiannelida) from the central coast of New South Wales. Aust. J. Mar. Freshwater Res. 32:439-456.

Gerlach, S. A. 1953. Zur Kinntnis der Archianneliden des Mittelmeeres. Kiel. Meeresforsch. 9:248-251.

Gray, J. S. 1969. A new species of Saccocirrus (Archiannelida) from the west coast of North America. Pac. Sci. 23:238-251.

Jouin, C. 1971. Status of the knowledge of the systematics and ecology of Archiannelida. Smithson. Contrib. Zool. 76:47-56.

1975. Étude de quelques Archiannélides des côtes d'Afrique du Sud: Description de Saccocirrus beterocbaetus n. sp.
(Archiannélide, Saccocirridae). Cah. Biol. Mar. 16:97-110.

Jouin, C., and G. C. Rao. 1987. Morphologi$\mathrm{cal}$ studies on some Polygordiidae and Saccocirridae (Polychaeta) from the Indian Ocean. Cah. Biol. Mar. 28:89-402.

Kirsteuer, E. 1967. Bredin-ArchboldSmithsonian biological survey of Dominica. 3. Marine archiannelids from Dominica. Proc. U.S. Natl. Mus. 123 (3610): 1-6.

Marcus, E. du B.-R. 1946. On a new archiannelid, Saccocirrus gabriellae, from Brazil. Comm. Zool. Mus. Hist. Nat. Montevideo 2 (37): 1-6.

1948. Further archiannelids from Brazil. Comm. Zool. Mus. Hist. Nat. Montevideo 2 (48): 1-27.

Martin, G. G. 1977. Saccocirrus sonomacus $\mathrm{n}$. sp., a new archiannelid from California. Trans. Am. Microsc. Soc. 96:97-103.

Pettibone, M. H. 1982. Classification of Polychaeta. Pages 1-43 in S. P. Parker, ed. Synopsis and classification of living organisms. Vol. 2. McGraw-Hill, New York.

Pierantoni, U. 1907. Il genere Saccocirrus Bobretzky e le sue specie. Ann. R. Mus. Zool. R. Univ. Napoli 2:1-11.

Rouse, G. W., and K. Fauchald. 1997. Cladistics and polychaetes. Zool. Scr. 26 (2): 139-204.

Russo, A. R., E. A. Kay, J. H. Bailey-Brock, and W. J. Cooke. 1997. Benthic sampling adjacent to the Wai'anae Ocean Outfall, O'ahu, Hawai'i, July 1997. Project Report PR-98-11, Water Resources Research Center, University of Hawai'i at Mānoa, Honolulu. 146 pp.

Sasaki, S. 1981. A new species of the genus Saccocirrus (Archiannelida) from Hokkaido, northern Japan. Annot. Zool. Jpn. 54 (4): 259-266.

Silberbauer, B. I. 1969. Archiannelids of the genus Saccocirrus from southern Africa. Trans. R. Soc. S. Afr. 38 (2): 165-182.

Swartz, R. C., J. H. Bailey-Brock, W. J. Cooke, and E. A. Kay. 2002. Regional monitoring of benthic fauna in Māmala Bay, O'ahu, Hawai'i, August 2001. Project Report PR-2002-07, Water Resources Research Center, University of Hawai'i at Mānoa, Honolulu. 158 pp. 
Westheide, W. 1985. The systematic position of the Dinophilidae and the archiannelid problem. Pages 310-326 in S. Conway Morris, J. D. George, R. Gibson, and H. M. Platt, eds. The origin and relationships of lower invertebrates. Oxford University Press, England.
1990. Polychaetes: Interstitial families. Keys and notes for the identification of species. Universal Book Services and Dr. W. Backhuys, Avon.

Yamanishi, R. 1973. A new species of Saccocirrus (Archiannelida) in Japan. Publ. Seto Mar. Biol. Lab. 21 (2): 73-76. 